\title{
GROWTH AND YIELD OF SHALLOT LEMBAH PALU VARIETY ON DIFFERENT DIRECTION AND FORM OF SEEDBEDS GROWING ON DRY LAND
}

\author{
Muhammad Ansar ${ }^{1)}$, Imam Wahyudi) and Bahrudin ${ }^{1)}$ \\ ${ }^{1)}$ Lecturer and Researcher at Department of Agrotechnology Faculty of Agriculture. University of Tadulako. Palu. \\ email: apasigai@yahoo.com
}

\begin{abstract}
This study aimed to determine the growth and yield of shallot Lembah Palu variety planted on dry land with different direction and form of seedbeds. It have been carried out in January-April 2013 in the village of Guntarano, Tanantovea Sub Districts, District of Donggala, Central Sulawesi. This study used a Spilt Plot Design. The main plot was the seedbed direction (A) consisting of: $(\mathrm{A} 1)=$ seedbeds in the direction of the slope of the land, and $(\mathrm{A} 2)=$ seedbeds crossed the slope direction. Sub-plot was the form of beds (B) comprises of: (B1) $=$ depth seedbeds and (B2) $=$ high seedbeds. Each treatment was repeated 3 times, so that there were 12 experimental units. The research found that (i) the direction of the beds as well as its interaction with the form of beds did not significantly affect the growth and yield of shallot 'Lembah Palu' on dry land. (ii) depth seedbeds produces the number of leaves, leaf length, leaf dry weight, total leaf area per plant, and total dry weight per plant, and the number of tubers per clump and the weight of the harvested dry tuber per hectare was higher than high seedbeds form.
\end{abstract}

Key Words : Direction, form, onion, seedbeds.

\section{INTRODUCTION}

Red onion known as flavorings food and pharmaceuticals (Rukmana, 1994). The use of red onion on a wide range of menu dishes is no stranger, either as a flavor enhancer and beauty (aesthetics) on the menu, as well as a source of vitamins and minerals. Results of the analysis for each $100 \mathrm{~g}$ onion bulbs containing $1.5 \mathrm{~g}$ of protein, $0.3 \mathrm{~g}$ of fat, $9.2 \mathrm{~g}$ of carbohydrates, $36 \mathrm{~g}$ of calcium, $40 \mathrm{~g}$ of iron, $0.03 \mathrm{~g}$ of vitamin $\mathrm{B}, 2.0 \mathrm{~g}$ of vitamin $\mathrm{C}$ and $88 \mathrm{~g}$ of water (Wibowo, 1992).

In Central Sulawesi, there is local red onion that have distinctive characteristics, and is known by red onion "Lembah Palu" variety (Allium cepa L. Agregatum groups) that have been released by the Ministry of Agriculture, as the superior national shallot (Minister of Agriculture, 2011). The shallots have been developed by the societies in Palu city, as well as parts of Donggala and
Sigi areas. The shallots have been well known as a raw material for making hig h-quality fried onions, because it has a dense texture, delicious tastes and has a distinctive aroma, so many favored to seasoning or as a snack. Thus, the shallot is including typical commodities which have high competitiveness that needs to be pursued development (Diperta Sulteng, 2005).

Most of the shallots or approximately $87.5 \%$ cultivated on dry land of dry climate in The Palu Valley (Bahrudin and Muhammad-Ansar, 2013), so that the availability of water is often a problem in increasing the onion production. The shallot cultivation system in Palu valley is very diverse, especially in the way or form of seedbeds. At the location center of the shallot in the village of Guntarano, the shallot cultivated using the form of "Depth Seedbeds", while in other shallot centers such as in the village of Solouwe using the form of "High Seedbeds". 
Shallots are needed by almost everyone, especially for seasoning various types of cuisine. Thus the demand for shallot products is increasing every year in line with population growth and food industries, in particular instant food using red onions as flavorings, but the increase in demand has not been accompanied by an increase in crop production. This is due to extensive cultivation of onion and productivity is still low.

Total shallot production in Central Sulawesi in 2011 was 20.228 tonnes (BPS Sulteng, 2012), while production of shallot in Donggala is 257 tons with an average productivity of 5.04 t/ha (BPS Donggala, 2012). The results are still relatively low due to the potential yield of the shallot can reach $9.7 \mathrm{t} / \mathrm{ha}$ (Minister of Agriculture, 2011).

Environmental conditions with adequate water supply is very suitable for growing early shallot crop, subsequent hot and dry conditions required in the maturation phase, harvesting and drying (Cys et al. 1993). Development of local shallot farming done on dry land, both on flat land conditions and steeper with technology implementation pickup, including a raised bed that is not technically considered aspects of soil and water conservation, but only consider the practical aspect and simplicity, especially in provision of water, so that the productivity is low and there is a growing tendency to decline from year to year due to declining soil fertility. Directions seedbed planting will be highly dependent on the slope. Land slope above the level of $8 \%$ is strongly recommended to follow the contour planting by adjusting cropping patterns and equipped with terraces manufacture (Arsyad, 1989). Shallot planting is generally done with beds and trench systems to facilitate the irrigation and disposal of excess water. Seedbed serves as a place of planting, while trench serves, beside as irrigation channels also act as a drainage channel (Rahayu and Berlian, 2007).
Planting beds were built cutting direction of the slope will function in restraining the rate of water loss through run off and loss of soil layers along with nutrients through the process of soil erosion. Instead directions beds are built in the direction of the slope will be very influential in accelerating decay and decline of soil fertility due to erosion process will take place very intensively (Arsyad, 1989). If this condition happen a long period continuously it will have a negative impact on growth and crop production, because of the declining ability of the soil to absorb and store water so that the plants will suffer water shortages processes that impact on inhibition of plant physiological processes. For plant growth, environmental factors, especially the availability of water may be the main limiting factor for the growth and yield of shallot on dry land, due to the ongoing destruction of land from season to season planting.

Soil degradation can occur through four processes, namely: the loss of nutrients from the root zone, declining soil organic matter content, accumulation of compounds or elements that are toxic to plants, erosion and surface run off, which causes the loss in excessive one or more nutrients from the root zone has resulted in decreased soil fertility and is unable to support normal plant growth and productivity becomes very low (Dirjen Tanaman Pangan, 1986). Thus soil conservation efforts, which means the placement of each plot on how to use according to the ability of the soil and treat it in accordance with the conditions necessary to avoid damage to the land is one of the efforts that need to be done, in order to increase soil infiltration capacity, as well as keeping the state of the soil to be resistant to power of destroys grain transport by rain and run off (Dirjen Tanaman Pangan, 1986).

Technical built of seedbeds at the location of development centers of the shallot in the village of Guntarano can be found in various forms that there are 
seedbeds stretched in the direction of the slope by using the form "depth seedbeds" surrounded by bund to allow water to flow into the beds and there similarly seedbed crosswise directionof the slope or direction of the land contour with "high seedbeds" were surrounded by a moat. Tillage, developing of seedbeds and planting in direction of the slope will cause great erosion due to runoff that carries the particles including nutrients and soil organic matter with no one to hold (Dirjen Tanaman Pangan, 1985). The damage due to the soil erosion, can cause deterioration chemical properties of soil and soil physical such as loss of nutrients and organic matter and the deteriorating physical properties are reflected by decreasing soil infiltration capacity and ability to retain water, increasing density and resilience soil penetration and reduced soil structure stability, which can led to deterioration in growth and declining crop productivity (Arsyad, 1989).

Thus both the direction and shape of these beds need to be examined to determine its effect on the growth and yield of the shallot, because of both the direction and shape of the beds there is a difference in the ways of water management, including in relation to the management of water and nutrients to the needs the plant during its growth.

Under these conditions it is necessary to conduct research that aims to study and determine the effect the direction and form of beds on the growth and yield of the shallot on dry land. The result is expected to be a source of technical information on a developing of good seedbeds especially the direction and form of seedbeds that can achieve the results for shallot cultivation in dry land.

\section{MATERIALS AND METHODS}

The research was conducted in the village of the Guntarano Village, Tanantovea Sub district, Donggala District, Central Sulawesi, in January-April 2012.
Materials and Methods. The materials used in these experiments include shallot seeds of "lembah palu", varieties, organic fertilizer of goat manure, inorganic fertilizers (Urea, SP36 and $\mathrm{KCl}$ ), pesticides and fungicides. The equipments used were hoes, shovels, scales, meter, board labels, raffia roof, handsprayer, ruler, and stationery.

This study used a Split Plot Design, repeated three (3) times. The main plot was the Directions of Beds (A) consists of two (2) levels ie: (A1) = the bad built up in the direction of slope and $(\mathrm{A} 2)=$ the bad built that cross the slope. Sub plots were Beds Form (B) consists of two levels, namely: $(\mathrm{B} 1)=$ depth bed and (B2) $=$ high bed. To determine the effect of treatment tested on plants, it is analysed by analysis of variance, and if the treatment has a significant effect, it continually tested by $\operatorname{HSD}(\alpha=0.05)$.

Implementation of Research. Soil tillage has done twice with plow before planting, with an interval of one week, then proceed with the built of trial seedbeds by the size of width of $1.0 \mathrm{mx} 7.0 \mathrm{~m}$ long, with a total of seedbeds of 12 plots. The distance of treatment plot in replicated plots was $0.5 \mathrm{~m}$, while the distance between replications plot is $0.75 \mathrm{~m}$.

The seedbeds was based on the direction and shape of each treatment, ie the direction of the slope and cross the direction of the slope, as well as beds with a form of "depth beds" and "high beds". Seedbed direction of the slope made by means of long beds of 7.0 transverse direction of the slope and is the main plot. Then in the direction of the slope seedbed is made in two forms, namely beds beds shaped "depth beds" surrounded by a dike and beds in the shaped of "high beds" as high as $25 \mathrm{~cm}$ which is surrounded by a moat, where the beds was a subplot. Similarly seedbed in the direction of the slope made by long stretches 7.0 beds unidirectional slope and the main plot, next to the slope direction of the seedbed is made in two forms, namely beds beds shaped "depth beds" with depth 
of about $20 \mathrm{~cm}$ surrounded by a dike and beds shaped of "high beds" were surrounded by a moat as a subplot.

Seeds planted by drill and placed upright in the planting hole with tubers position flush with the soil surface. Planting is done with a spacing of $20 \mathrm{~cm} \times 20 \mathrm{~cm}$, so that in each experimental plot contained 175 plants population shallot. Once the seeds are planted, daily watering with water entering into the ditch and beds until the soil getting water completely or reach field capacity.

The fertilizer applied $200 \mathrm{~kg}$ urea/ha, $200 \mathrm{~kg} \mathrm{SP36/ha}$ and $100 \mathrm{~kg} / \mathrm{KCl}$. SP36 and $\mathrm{KCl}$ was given one week after planting (MST), while urea was given in 2 step, it was given $1 / 2$ rate at age of $1 \mathrm{MST}$ and the remaining $1 / 2$ rate was given at the age of 35 HST. The fertilizer was given by bolt system.

Plant maintenance includes weeding, tilling the soil and control pests and plant diseases. Weeding is intended to remove weeds to avoid the competition with staple crop and conducted in accordance with the conditions of the weeds that grow in the planting area. Tilling the soil is done on each onion plants which aims to facilitate the growth and development of plant roots shallot. Pest control during the study only done physically ie killing the pests directly and attack the plants. Intensity control that has been done only twice during the study.

Harvesting is done at the age of the plant was 70 day after planting with indicated by yellow leaves, dry and fall, bulbs has been enlarged and most have appeared on the surface of the soil. Harvesting is done by pulling the sample and tile plants first, then followed by other crops. After the bulbs removed immediately cleaned of soil attached, then dried a few days after harvest.

Observation. To see the effect of direction and form of seedbeds, then it was done observations of plant growth at the age of 45 day after planting (DAP) include: number of leaves, leaf length, leaf dry weight, and total dry weight per plant, and yield components observations include: the number of tubers per hill, harvested tuber dry weight and fresh tuber weight per hectare.

Observation of total plant dry weight and total leaf area per plant is done by dismantling the plants from growing media, clean up, and then oven dried at a temperature of $80^{\circ} \mathrm{C}$ for $2 \times 24$ hours or until a constant dry weight. Total leaf area per plant, calculated by the method of weighing (gravimetric) with a dry weight basis of leaves, according Kandhakar (1994) with the following formula:

$$
\mathrm{LD}=\frac{\mathrm{LDs}}{\mathrm{BkDs}}
$$

Where:

$$
\begin{aligned}
\mathrm{LD} & =\text { Leaf area per plant }\left(\mathrm{cm}^{2}\right) \\
\mathrm{LDs}= & \text { Leaf area of leaf sample }\left(\mathrm{cm}^{2}\right) \\
\text { BkDs }= & \text { Dry weight of leaf samples which } \\
& \text { have been known the leaf area }(\mathrm{g}) \\
\text { BkDt }= & \text { Total ofleaf dry weight per plant }(\mathrm{g})
\end{aligned}
$$

Data Analysis. The data have been obtained, it then were analysed by Anova according Gomes and Gomes (1995) and if the F test results showed that the treatment given real effect, it is done bya further testusing the test honestly Significant Difference (HSD) at $\alpha$ confidence level of 0.05 .

Table 1. Average Number of Leaves, Leaf Length, Leaf Dry Weight, The Longest Leaf Area and Total Dry Weight of Shallot at The Age Of 45 Days After Planting on The Form of Seedbeds The Treatment

\begin{tabular}{lccccc}
\hline $\begin{array}{c}\text { The Form of } \\
\text { Seedbeds }\end{array}$ & $\begin{array}{c}\text { Number of } \\
\text { Leaves (Pieces) }\end{array}$ & $\begin{array}{c}\text { Leaf Length } \\
(\mathrm{cm})\end{array}$ & $\begin{array}{c}\text { Leaf Dry Weight } \\
(\mathrm{g} / \mathrm{plant})\end{array}$ & $\begin{array}{c}\text { The Longest } \\
\text { Leaf Area }\left(\mathrm{cm}^{2}\right)\end{array}$ & $\begin{array}{c}\text { Total Dry } \\
\text { Weight }(\mathrm{g} / \mathrm{plant})\end{array}$ \\
\hline Deep Seedbed & $20,50 \mathrm{a}$ & $18,31 \mathrm{a}$ & $0,497 \mathrm{a}$ & $151,08 \mathrm{a}$ & $1,31 \mathrm{a}$ \\
Highbeds & $17,60 \mathrm{~b}$ & $14,74 \mathrm{~b}$ & $0,388 \mathrm{~b}$ & $118,44 \mathrm{~b}$ & $1,02 \mathrm{~b}$ \\
\hline HSD $(\dot{\alpha}=0.05)$ & 2,03 & 2,07 & 0,079 & 23,68 & 0,16 \\
\hline
\end{tabular}

Note : The Average Number Followed by The Same Letterin The Same Column Showed No Significant at $\alpha$ HSD Test Level of 0.05 . 
Table 2. The Average Number of Tubers Per Hill and Harvested Tuber Dry Weight of Shallot Per Hectare on The Treatment Form of Beds

\begin{tabular}{lcc}
\hline \multicolumn{1}{c}{ The Form of Beds } & $\begin{array}{c}\text { The Number of Tubers Per } \\
\text { Clump (Pieces) }\end{array}$ & $\begin{array}{c}\text { Harvesting The Tubers Dry } \\
\text { Weight (Ton/ha) }\end{array}$ \\
\hline Deep Seedbed & $9,65 \mathrm{a}$ & $12,49 \mathrm{a}$ \\
Highbeds & $8,02 \mathrm{~b}$ & $11,29 \mathrm{~b}$ \\
\hline HSD $(\dot{\alpha}=0.05)$ & 1,27 & 1,01
\end{tabular}

Note : The Average Number Followed by The Same Letter in The Same Column Showed no Significant at $\alpha$ HSD Test Level of 0.05 .

\section{RESULTS AND DISCUSSION}

\section{Research Result.}

Number of Leaves. Results of variance showed that the interaction of seedbed direction and form of seedbeds did not significantly affect on the number of leaves of the shallot, while the form of seedbeds have significantly affect on the number of shallot leaf at the aged of 45 days after planting. $0.05 \alpha$ HSD analysis results (Table 1) shows that the form of "depth seedbeds" can produce the highest number of leaves and significantly different from the form of "high seedbeds" at the age of 45 days after planting.

Leaf Length. Results of variance showed that the interaction seedbed direction and form of beds did not significantly affect on leaf length of the shallot, while the form of beds significantly affect on leaf length at the aged of 45 days after planting. A HSD test result of 0.05 (Table 2) shows that the form of "deep seedbeds" produces longer leaves and significantly different from the form of "high seedbeds" at the age of 45 days after planting.

Dry Weight of Leaves Per Plant. Results of variance showed that the interaction seedbed direction and form of beds did not significantly affect on the dry weight of leaves per plant of shallot. The form of seedbeds significantly affect on the dry weight of the leaves at the aged of 45 days after planting. While the direction of the seedbeds did not significantly affect the dry weight of the leaves of shallot at the age of 45 days after planting. $0.05 \alpha$ HSD test results (Table 1) showed that the form of deep seedbeds can produce higherdry weight of shallot leaves and significantly different from the form of a high seedbeds at the age of 45 days after planting.

Longest Leaves Area. Results of variance showed that the interaction seedbed direction and form of beds did not significantly affect on the longest leaf area of shallot. The form of beds significantly affect on the longest leaf area at the age of 45 days after planting. While the direction of the beds did not significantly affect on the longest leaf area of shallotat the age of 45 days after planting. $0.05 \alpha$ HSD test results (Table 1) shows that the form of "deep seedbeds" produces more wider of the longest leaf area of the shallot and significantly different from the form of "high seedbeds" at the age of 45 days after planting.

Dry Weight Total Per Plant. Results of variance showed that the interaction seedbed direction and form of beds did not significantly affect on the total dry weight per plant of shallot. The form of beds significantly affect the total dry weight per plant of shallot at the age of 45 days after planting. $0.05 \alpha$ HSD analysis results (Table 1) shows that the form of deep beds can produce greater total dry weight per plant of shallot and significantly different from the form of a high beds at the age of 45 days after planting.

Number of Bulbs Per Clump. Results of variance showed that the interaction seedbed direction and form of beds did not significantly affect onthe number of tubers per hill of the shallot; while the direction 
and form of beds each of them has significantly affect onthe number of tubers per hill of the shallot. AHSD test result of 0.05 (Table 2) shows that the form of beds produce higher the number of tubers per hill of shallot and significantly different than the form of high seeds bed.

\section{Harvest Dry Weight Bulbs Per Hectare.} Results of variance showed that the interaction seed bed direction and form of beds did not significantly affect on the weight of harvested dry tuber; whereas the form of beds significantly affect on the harvested dry weight of bulb of shallot. AHSD test result of 0.05 (Table 2) shows that the form of beds produce higher the harvested dry weight of bulb of the shallot per hectare and significantly different than the form of high seedbeds.

\section{DISCUSSION}

Plant growth is the result of interactions between plants factors (genetic) and environmental factors in which they are grown. One of the environmental factors that have a very important role in the metabolism, growth and development of plants is water. Thus the availability of water according to the needs of plants at each growth stage is very important to get attention. Furthermore, directions and form of seedbeds closely related in the affect on the availability of water for the shallot grown on dry land.

The results showed that the interaction between the direction and form of beds and single factor of beds direction did not significantly affect on the growth and yield of shallot. This can be caused by two factors tested which have not been in optimal conditions to be able to act jointly in affecting the growth and development of shallot plants. Another thing that may cause such a way that the water supply has not been able to provide the maximum soil waterto fulfill the shallot demand, because both factors closely related to the soil's ability to obtain, store and release water for plant growth, especially in conditions of dry land that irrigation depends on irrigation water. As noted by Arsyad (1989) that the direction and shape of the planting beds should be adapted to the soil and climatic conditions, especially rainfall, which the form of depth beds can serve as a container that can hold water so can increase the availability of water, while the high beds can reduce puddles of water that can damage crops in conditions of high rainfall.

Furthermore, treatment of beds form can give significant effect on the growth of the shallot, which the form of deep seedbeds can provide a better growth of the number of leaves, leaf length, leaf dry weight, total leaf area per plant and total dry weight per plant. This may reflect that the research location which is dry land, the use of deep beds is being very effective role in improving soil moisture content utilized by plant growth. In the form of "deep seedbeds", water will be retained longer in the soil, so that the amount of water with nutrients will be more available in the soil so that it can support the establishment of onion plant leaves. As stated De Visser (1988) that the establishment leaves much influenced by the supply of nutrients along with water-soluble, but nutrient leaching will be happened together with watering when watering or water delivery techniques are not appropriate. Nutrient leaching can reach $50 \%$ and $58 \%$ on less precise water management (Hayashi and Hatana, 1999). Similarly, the dry weight of the leaves per plant is largely determined by the size of leaves and number of leaves per plant of the shallot. More number of leaves with a longer leaf size obtained in the treatment of "deep beds" will cause crop leaf dry weight was also higher. Leaf dry weight of the plant is an overview of the results of the ongoing photosynthesis in plants. The rate of photosynthesis will be strongly influenced by the water and nutrients that can be utilized in the plant growth. This corresponds proposed by Ciauskas et al. (2001) that the nutrients are 
absorbed by plants, especially macro nutrients, will be used for the shallot growth and development.

In the form of high seedbeds, water is relatively less available to plants, so the growth is not as good as grown on deep seedbeds. As noted by Nielson et al. (2002) soil management relates to conditions of water shortages and better plant growth conditions throughout the growing season. The use of high seedbeds on dry land will cause fast drying of the beds due to lack of water caused by evaporation and downward movement of water through infiltration, in a long period of time will cause the shallot will suffer water stress. This will lead to low soil productivity due to water becomes a limiting factor as a result of the soil's ability to hold and store water is low, high infiltration and evaporation, fertility and organic matter is very low and low water use efficiency (Al-Omran et al., 2004). In this case that the important thing in the management of irrigation water is irrigation frequency and the amount of water given to each phase of plant growth.

Similarly to the shallot yield components, treatment of deep seedbeds can provide results the number of tubers per hill, tuber dry weight per hill and tuber yield per hectare is higher than the form of high seedbeds. This is, beside caused by the availability of water is relatively lower in the high seedbeds than in deep seedbeds, also because of the high seedbeds requires the amount of water, time and water pressure were relatively moreto increase the water content of the soil than deep seedbeds. This relates to that proposed by Winarba (2000) that the irrigation method should be determined by the depth of the soil layer saturated by water, horizontaly water distribution and periods of potential water stress, where it is an important factor and a very large impact on crop production. This shows that the water in addition to a role in improving vegetative growth can also increase crop yields. Water function in plants is essential, so if water is available in sufficient quantities needed by plants in each phase of growth, it will directly increase the rate of growth which in turn will help determine crop yield. The water in the plant act primarily as raw materials of photosynthesis, solvent media and nutrient transport, the main constituent of protoplasm as well as reagents of many important processes in the body of plants (Salibury and Ros, 1992). Results of the study Muhammad-Ansar et al. (2012), found that the 'Lembah Palu' shallot is cultivated in lowland altitude of $100 \mathrm{~m}$ above sea level require moisture (soil moisture) higher than the $100 \%$ of field capacity, due to the high temperatures caused crop transpiration rate is always higher than the high altitude of 800 meters above sea level.

\section{CONCLUSIONS AND SUGGESTIONS}

\section{Conclusion}

There was no significant interaction between treatment of beds direction and form of beds on the growth and yield of "Lembah Palu" shallot on dry land Guntarano village.

The treatment of beds directions did not significantly affect on the growth and yield of "Lembah Palu" shallot.

The form of deep seedbeds can produce growth in the number of leaves, leaf length, leaf dry weight, leaf area and the longest total dry weight per plant higher and the number of tubers per hill and severe harvested dry bulb of "Lembah Palu" shallotis higher than the form of "high seedbeds".

\section{Suggestion}

From the results obtained can be advised to conduct similar research by combining the provision of water treatment interval with organic and inorganic fertilizers. 


\section{REFFERENCES}

Al-Omran, A.M.; A.M. Falatah; A.S. Sheta and A.R.Al-Harbi. 2004. Clay Deposits for Water Management of Sandy Soils. Arid Land Research and Management 1: 171-183.

Arsyad, S. 1989. Konservasi Tanah dan Air. IPB Press. Institut Pertanian Bogor. Bogor.

Bahrudin dan Muhammad-Ansar, 2013. Potensi dan Karakteristik Budidaya Bawang Merah di Lembah Palu Sulawesi Tengah. Makalah Seminar Nasional FKPTPI. Palu. November 2013.

BPS Donggala, 2012. Kabupaten Donggala dalam Angka. Badan Pusat Statistik Kabupaten Donggala. Donggala.

BPS Sulteng, 2012. Sulawesi Tengah Dalam Angka. Badan Pusat Statistik Propinsi Sulawesi Tengah. Palu.

Ciauskas, A; J. N. Sorensen; K. Grevsen and P Viskelis. 2001. Effects of N Fertilization on Yield, Quality and Storability of Onions. XXVI th International Horticultural Conggres. (abstract).

Cys, C., E van Ranst, J. Debaveye and F. Beernaert. 1993. Land Evaluation. Part III Crop Requirements. Agricultural Publications-No. 7; General Administration for Development Cooperation. Belgium.

De visser, C. I. M. 1998. Effect of Split Application of Nitrogen on Yield and Nitrogen Recovery of Spring-Sown Onions and On Residual Source. J. of Horticultural Science and Biotech. 73: 403-411.

Diperta Kota Palu. 2007. Petunjuk Teknis Pengembangan Agribisnis Bawang Merah Lokal Palu Tahun 2007. Dinas Pertanian. Kehutanan dan Kelautan Kota Palu. Palu.

Diperta Sulteng. 2005. Profil Bawang Merah Lokal Palu. Sub-Din Bina Pengolahan dan Pemasaran Hasil Dinas Pertanian Perkebunan dan Peternakan Sulawesi Tengah. Palu.

Dirjen Tanaman Pangan, 1985. Kerusakan Tanah dan Cara Memperbaikinya. Direktorrat Jenderal Pertanian Tanaman Pangan. Direktorat Perluasan Areal Pertanian. Jakarta.

Dirjen Tananaman Pangan, 1986. Perencanaan Usahatani Konservasi. Direktorrat Jenderal Pertanian Tanaman Pangan. Direktorat Perluasan Areal Pertanian. Jakarta.

Gomez, K.A. and A.A.Gomez. 1995. Prosedure Statistik untuk Penelitian Pertanian. Terjemahan Endang Syamsuddin dan Justika S Baharsjah. Edisi kedua. UI-Press. Jakarta.

Hayashi, Y., and R. Hatano. 1999. Annual Nitrogen Leaching to Sub Surface Water from Clayey Aquic Soil Cultivated with Onions in Hokkaido Japan. Soil science and Plant Nutrition. 45: 451-459.

Khandakar. 1994. Manual of methodes for Physio-morphological Studies of Jute, Kenaf and Allied Germplasm. International Jute Organisation. Dhaka. Baangladesh. P. 11-15.

Mentan. 2011. Surat Keputusan Menteri Pertanian tentang Pelepasan Bawang Merah Varietas Lembah Palu Sebagai Varietas Unggul. Menteri Pertanian Republik Indonesia. Jakarta.

Muhammad-Ansar, Tohari, B.H. Sunaryanto dan E. Sulistyaningsih, 2012. Pengaruh Lengas Tanah Terhadap Pertumbuhan Dan Hasil Tiga Varietas Lokal Bawang Merah Pada Ketinggian Tempat Berbeda. J. Agroland. 18 (1): 8-18.

Nielsen, D.C., P.W. Unger \& P.R. Miller., 2002. Efficient Water Use in Dryland Cropping System in the Great Plains. Agron .J. 97: 364-372 (2005). American Society of Agronomy. USA.

Rahayu, E. dan N. Berlian, V.A. 2007. Bawang Merah. Penebar Swadaya. Jakarta.

Rukmana, R. 1994. Budidaya dan Pengolahan Pasca Panen Bawang Merah. Kanisius. Yogyakarta.

Salisbury, F.B. and C.W. Ross. 1992. Plant Physiology. Wadsworth Publ. Co. Belmont California.

Wibowo, S., 1992. Budidaya Bawang Merah. Penebar Swadaya. Jakarta.

Winarba, S. 2000. Pengaruh Kadar Air Tanah Terhadap Pertumbuhan dan Produksi Dua Tipe Kapolaga Sabrang. Bul. Agron. (28) (1) 1-8 (2000). 